\title{
Membedah Kebijakan Perencanaan Ketenagalistrikan di Indonesia
}

\author{
Grita Anindarini Widyaningsih ${ }^{303}$
}

\section{Pendahuluan}

Saat ini, tingginya angka emisi gas rumah kaca menjadi fokus di berbagai negara, termasuk Indonesia. Sebagai pemicu adanya pemanasan global, dan yang lebih jauh adalah perubahan iklim, berbagai negara kini gencar menginventarisasi dan melakukan langkah-langkah strategis untuk mengendalikan tingginya angka tersebut. Indonesia sendiri, menurut dokumen strategi penerapan Nationally Determined Contribution (NDC), nyatanya telah mencapai $1.334 \mathrm{M}$ Ton $\mathrm{CO}_{2 \mathrm{e}}$ per 2010 untuk angka emisi gas rumah $\mathrm{kaca}^{304}$. Tidak hanya itu, angka ini diperkirakan akan meningkat 3,9\% pada tahun 2030 dan akan semakin meningkatkan risiko naiknya temperatur global kedepannya.

Sebagai tindak lanjut dari permasalahan ini, Indonesia telah berkomitmen untuk berusaha menurunkan emisi gas rumah kaca dengan mengadopsi Paris Agreement to the United Nations Framework Convention on Climate Change dan meratifikasinya melalui UU No. 16 Tahun 2016 tentang Pengesahan Paris Agreement to the United Nations Framework Convention on Climate Change (Persetujuan Paris atas Konvensi Kerangka Kerja Perserikatan Bangsa-Bangsa Mengenai Perubahan Iklim). Adapun fokus dari konvensi tersebut adalah menahan kenaikan suhu rata-rata global di bawah $2^{\circ} \mathrm{C}$ di atas tingkat di masa pra-industrialisasi dan melanjutkan upaya untuk menekan kenaikan suhu $1,5^{\circ} \mathrm{C}$ di atas tingkat pra-industrialisasi.

Lebih jauh, adanya komitmen dari Paris Agreement tersebut kemudian diejawantahkan dalam Nationally Determined Contribution. Dalam dokumen ini, Indonesia menyampaikan komitmen untuk

303 Penulis adalah Asisten Peneliti Indonesian Center for Environmental Law

304 Nur Masripatin, et.al. Strategi Implementasi Nationally Determined Contribution, (Jakarta: KLHK, 2017), hlm. 9. 
menurunkan emisi gas rumah kaca (mitigasi) pada tahun 2030 sebesar 29\% dengan kemampuan sendiri dan sampai dengan $41 \%$ bila dengan dukungan internasional, dibandingkan dengan tanpa aksi mitigasi ${ }^{305}$.

Terdapat 5 (lima) sektor yang menjadi fokus upaya penurunan emisi tersebut, yakni kehutanan, energi, pertanian, industri, dan limbah. Dari kelima sektor tersebut, sektor energi menempati peringkat kontribusi kedua dalam upaya penurunan emisi, yakni 11\%. Hal ini diperlukan karena memang tingkat emisi yang dihasilkan dari sektor energi mencapai 453,2 MTON CO 2 eer 2010 dengan rata-rata pertumbuhan tahunan tertinggi hingga 20 tahun ke depan, yakni 6,7\%306. Melihat hal tersebut, NDC 2017 telah menetapkan arahan untuk dekarbonisasi dalam pengembangan energi ke depannya.

Tentunya, komitmen NDC ini perlu untuk diterjemahkan dalam dokumen-dokumen perencanaan energi, khususnya sektor ketenagalistrikan yang sejalan dengan komitmen tersebut. Adapun dalam pemaparan dokumen NDC, untuk usaha mitigasi dari sektor energi mengacu pada penetapan yang ada di dalam Kebijakan Energi Nasional. Kebijakan ini menetapkan bahwa dalam hal bauran penyediaan energi utama, setidaknya harus mengakomodir $23 \%$ dari energi terbarukan pada tahun 2025.

Untuk mencapai target tersebut, Penulis berpendapat bahwa perlu melihat bagaimana perencanaan proyek ketenagalistrikan di Indonesia. Adapun perencanaan proyek ketenagalistrikan di Indonesia didasarkan atas 4 (empat) dokumen perencanaan, yakni:

a) Kebijakan Energi Nasional (KEN): KEN adalah sebuah kebijakan pengelolaan energi yang memuat tujuan, sasaran, hingga arah kebijakan energi nasional. Adapun kebijakan ini ditetapkan dalam Peraturan Pemerintah Nomor 79 Tahun 
2014 tentang Kebijakan Energi Nasional;

b) Rencana Umum Energi Nasional (RUEN): RUEN adalah sebuah dokumen yang berisi tentang penjabaran lebih rinci dari KEN, dan memuat kondisi energi nasional saat ini serta ekspektasi masa mendatang, hingga kebijakan dan strategi pengelolaan energi nasional. Ditetapkan dalam Peraturan Presiden Nomor 22 Tahun 2017 tentang Rencana Umum Energi Nasional, RUEN kemudian telah mengidentifikasi potensi sumber daya energi per provinsi dan target pembangunan pembangkit listrik tersebut hingga tahun 2050;

c) Rencana Umum Ketenagalistrikan Nasional (RUKN): RUKN merupakan sebuah dokumen yang bersifat indikatif yang berisikan tentang rencana pengembangan penyediaan tenaga listrik ke depan, kondisi penyediaan tenaga listrik saat ini, proyeksi kebutuhan tenaga listrik untuk 20 (dua puluh) tahun ke depan, dan potensi sumber energi primer di wilayah provinsi tersebut. Adapun hingga saat ini RUKN belum ditetapkan, meskipun rancangan final dari dokumen terkait telah dapat diakses bebas. Oleh karena itu, artikel ini menggunakan rancangan RUKN tahun 2018 sebagai bahan analisis;

d) Rencana Umum Penyediaan Tenaga Listrik (RUPTL): RUPTL merupakan dokumen yang berisi daftar proyek infrastruktur penyediaan tenaga listrik. Dokumen ini merupakan pedoman pengembangan sistem tenaga listrik di wilayah usaha PLN untuk sepuluh tahun mendatang. Adapun RUPTL yang menjadi acuan artikel ini adalah RUPTL 2018-2027, yang disahkan dalam Keputusan 
Menteri ESDM No. 1567 K/21/MEM/2018.

Berangkat dari hal tersebut, artikel ini bertujuan untuk mengkaji apakah arah kebijakan ketenagalistrikan di Indonesia dalam dokumen-dokumen tersebut telah sejalan satu dengan lainnya? Lebih jauh, artikel ini juga mengkaji apakah perencanaan ketenagalistrikan di Indonesia juga telah sesuai dengan target yang ingin dicapai dalam dokumen NDC?

Sebagai pengecualian, perlu untuk dipahami bahwa penyusunan rencana untuk penyediaan tenaga listrik dibedakan menjadi 2 (dua), yakni penyediaan tenaga listrik untuk kepentingan umum dan penyediaan tenaga listrik yang dilakukan secara terintegrasi dalam 1 (satu) wilayah usaha oleh satu badan usaha ${ }^{307}$. Untuk mempersempit lingkup pembahasan dalam artikel ini, pengaturan terkait perencanaan ketenagalistrikan yang akan dibahas terbatas pada yang terkait dengan penyediaan tenaga listrik untuk kepentingan umum.

\section{Arah Kebijakan Perencanaan Ketenagalistrikan di Indonesia}

Menurut Pasal 8 Peraturan Pemerintah Nomor 23 Tahun 2014 tentang Kegiatan Usaha Penyediaan Tenaga Listrik, penyusunan rencana penyediaan tenaga listrik untuk kepentingan umum ini dilaksanakan sesuai dengan Rencana Umum Ketenagalistrikan dan RUPTL. Lebih jauh, Rencana Umum Ketenagalistrikan ini dibagi menjadi 2 (dua), yakni RUKN dan Rencana Umum Ketenagalistrikan Daerah (RUKD).

Apabila ditilik kembali ke dasar hukumnya, Pasal 8 ayat (3) PP No. 23 Tahun 2014 menjelaskan bahwa RUKN itu sendiri disusun berdasarkan Kebijakan Energi Nasional (KEN) dan Rencana Umum Energi Nasional (RUEN). Adapun terkait dengan

307 Indonesia (a), Peraturan Pemerintah tentang Kegiatan Usaha Penyediaan Tenaga Listrik, Peraturan Pemerintah No. 14 tahun 2012, LN No. 28 tahun 2012, TLN No. 5281, Ps. 7 juncto Indonesia (b) Peraturan Pemerintah tentang Perubahan Atas Peraturan Pemerintah Nomor 14 Tahun 2012 tentang Kegiatan Usaha Penyediaan Tenaga Listrik, PP No. 23 Tahun 2014, LN No. 75 Tahun 2014, TLN No. 5530, Ps. 8. 
RUPTL, secara implisit dijelaskan dalam RUEN bahwa RUEN berfungsi sebagai rujukan dalam penyusunan RUPTL. Meskipun masih ada kerancuan akibat hukum dari terminologi "disusun berdasarkan" dan "sebagai rujukan" dalam konstruksi pengaturan tersebut, setidaknya perlu ada garis merah arah kebijakan perencanaan ketenagalistrikan di Indonesia dalam keempat dokumen tersebut.

Untuk mengkaji konsistensi arah kebijakan perencanaan ketenagalistrikan tersebut, tulisan ini mencoba untuk berangkat dari pendekatan Energy Trilemma Index (ETI) yang dipublikasikan oleh World Energy Council untuk mengukur performa kebijakan energi di masing-masing negara. Pada dasarnya, terdapat 3 (tiga) dimensi untuk mengukur indeks ini, yakni ${ }^{308}$ :

(1) Energy Security: bagaimana manajemen penyediaan energi dari dalam negeri maupun dari sumber eksternal. Selain itu juga bagaimana ketersediaan infrastruktur dan sejauh apa keterlibatan perusahaan di bidang energi untuk dapat berpartisipasi memenuhi permintaan energi untuk sekarang dan akan datang;

(2) Energy Equity: bagaimana keterjangkauan dan aksesibilitas warga negara tersebut terhadap penyediaan energi; serta

(3) Environmental Sustainability: bagaimana pencapaian terhadap efisiensi energi dan pengembangan terhadap energi terbarukan atau energi rendah emisi.

Apabila diterjemahkan ke dalam dokumen perencanaan energi dan ketenagalistrikan di Indonesia terkait dengan langkah-langkah untuk memenuhi seluruh aspek dalam ETI tersebut, maka arah kebijakan pengembangan energi dan

308 Lianlian Song, et.al., "Measuring National Energy Performance via Energy Trilemma Index: A Stochastic Multicriteria Acceptability Analysis", Energy Economics (2017), hlm. 313. 
ketenagalistrikan di Indonesia dapat

dipetakan sebagai berikut:

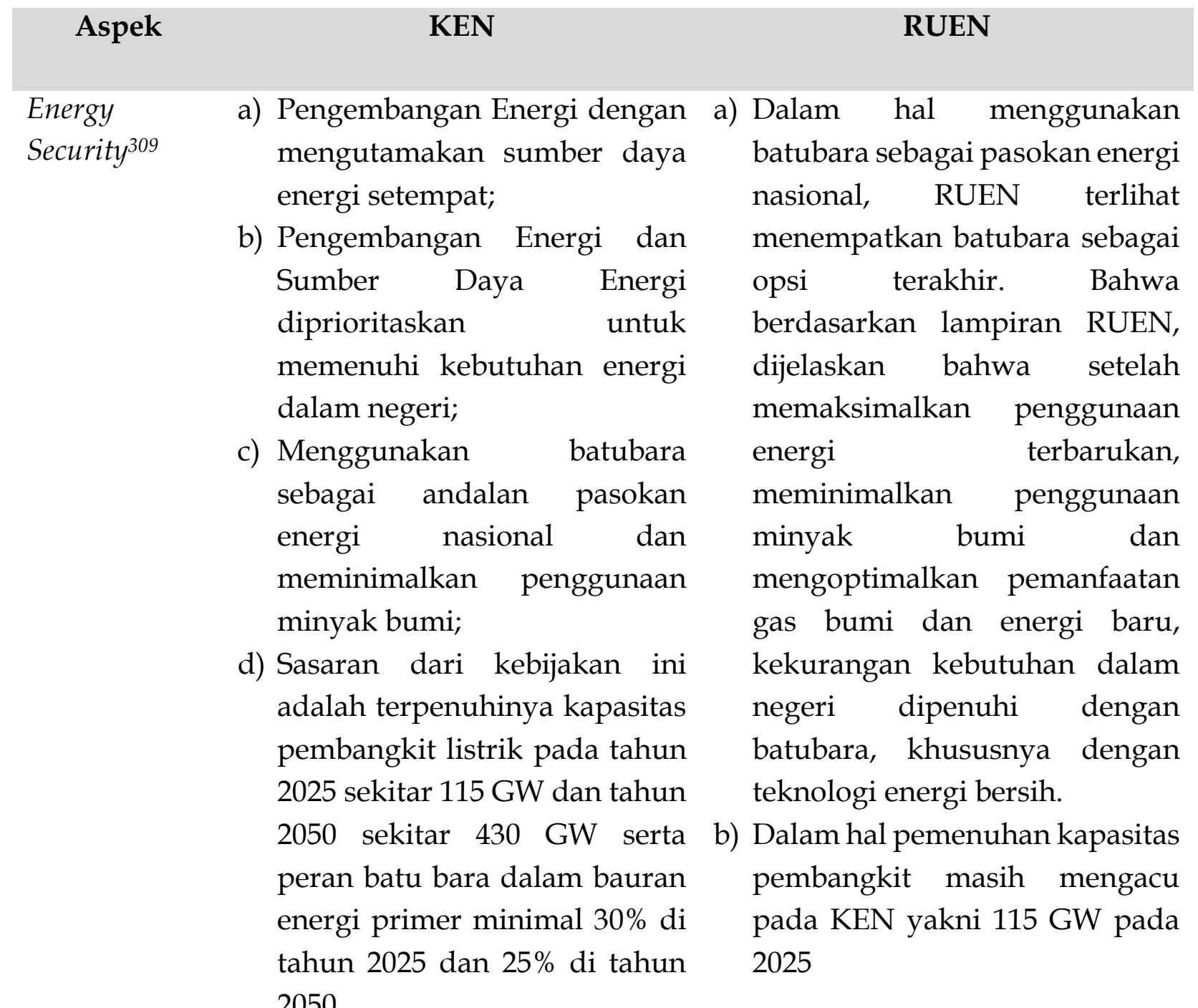

309

World Energy

Council,

Membedah

Perencanaan

Ketenagalistrikan, http://www.djk.esdm.go.id/pdf/Coffee\%20Morning/Juli\%202016/Membedah\%20Perencanaan\%20 Ketenagalistrikan\%20Nasional\%20--\%20Dr.\%20Hardiv\%20HS.pdf, diakses pada 18 Oktober 2018. Pada presentasi ini dijelaskan beberapa aspek untuk memenuhi energy security meliputi: a) Mengembangkan cross-border transaction, b) Mengembangkan energi rendah karbon dalam bauran energy mix nasional dan sesuai dengan kapasitas daerah setempat; c) Menumbuhkan investasi berskala besar untuk pengembangan pembangkit listrik berbasis energi terbarukan; d)pengembangan energi efisiensi; e) Memastikan penyediaan energi yang berkelanjutan dan infrastruktur untuk mendukung pengembangan pembangkit tersebut. Adapun untuk membatasil lingkup artikel ini dan untuk menyelaraskan dengan isu terkait target dalam NDC, aspek energy security yang akan dibahas hanya terfokus pada pengembangan energi dengan mengoptimalkan potensi daerah setempat dan usaha untuk pengembangan energi rendah karbon. 

Energy Equity 1) Memprioritaskan penyediaan energi bagi masyarakat yang belum memiliki akses terhadap energi listrik, gas rumah tangga, dan energi untuk transportasi, industri, dan pertanian;
2) Sasaran kebijakan ini adalah tercapainya rasio elektrifikasi sebesar $85 \%$ pada tahun 2015 dan mendekati $100 \%$ pada tahun 2020

Environmental Sustainability
1) Memaksimalkan penggunaan energi terbarukan dengan memperhatikan tingkat keekonomian

2) Sasaran dari kebijakan ini adalah tercapainya bauran energi dari energi terbarukan paling sedikit $23 \%$ pada tahun 2025 dan $31 \%$ pada tahun 2050.
1) Adapun hal ini juga diukur dari tercapainya rasio elektrifikasi sebesar $100 \%$ pada 2020.
1) Terkait dengan pengembangan energi terbarukan, hal yang perlu diperhatikan selain terkait ke-ekonomian (harga), namun juga perlu diperhatikan lingkungan, peningkatan aktivitas ekonomi, dan penyerapan tenaga kerja

2) Dalam RUEN, ditetapkan bahwa rencana jumlah total pembangkit dari EBT adalah 45 GW310 atau sekitar 33\% dari total keseluruhan pembangkit pada 2025. Oleh karena itu, target pembangkit ini terlihat ditetapkan lebih besar daripada yang ada di KEN.

Tabel 1. Perbandingan Arah Kebijakan Energi dengan Energy Trilemma Index ${ }^{311}$

310 Adapun angka $45 \mathrm{GW}$ tersebut dapat dicapai dari pemodelan sebagai berikut: a) Panas Bumi 7,2 GW; b) Air 17,9 GW; c) Minihidro dan Mikrohidro 3 GW; d) Bioenergi 5,5 GW; e) Surya 6,5 GW; f) Angin/Bayu 1,8 GW; dan g) Energi terbarukan lainnya 3,1 GW.

311 Data ini dihimpun oleh Penulis berdasarkan: a) Indonesia (c), Peraturan Pemerintah tentang Kebijakan Energi Nasional, PP No. 79 Tahun 2014, LN No. 300 Tahun 2014, TLN No. 5609; dan b) Indonesia (d), Peraturan Presiden tentang Rencana Umum Energi Nasional, LN No. 43 Tahun 2017. 
Dari data tersebut, dapat terlihat bahwa pada dasarnya untuk perencanaan ketenagalistrikan secara umum, kebijakan dalam RUEN telah menerjemahkan amanat-amanat yang ada di dalam KEN dengan baik, bahkan menargetkan pengembangan pembangkit dari EBT secara lebih ambisius daripada yang ditetapkan di dalam KEN. Disamping itu, dengan ditetapkannya batubara dengan teknologi bersih sebagai opsi terakhir sebagai pemenuhan energi nasional setelah mempertimbangkan energi terbarukan, juga menajamkan komitmen RUEN untuk menggenjot pengembangan energi terbarukan.

Namun, perlu diperhatikan bahwa target pembangunan 45 GW yang tercantum dalam RUEN kemudian dibagi menjadi 2 (dua) kelompok, yakni: a) Committed Project, sebesar 26.632,7 MW atau 26 GW dan b) Potential Project 18.520,5 MW atau 18 GW. Tidak jelas bagaimana penjelasan dari adanya committed project dan potential project ini. Sekalipun begitu, apabila perencanaan ini hanya bergantung pada committed project saja, maka pada dasarnya perencanaan dalam RUEN sudah sesuai dengan amanat KEN, yakni 23\% bauran untuk energi primer.

Kini pertanyaannya adalah apakah komitmen yang dibangun oleh KEN dan RUEN ini kemudian diterjemahkan secara sejalan dalam dokumen pelaksananya, yakni RUKN dan RUPTL? Terlebih ketika berbicara mengenai RUPTL. Dalam dokumen ini, target perencanaan yang dibangun dalam KEN dan RUEN kemudian perlu untuk diatur lebih lanjut per proyek dalam RUPTL. Untuk itu, penting untuk dikritisi dengan memperhatikan Energy Trilemma Index, apakah kebijakan dalam RUPTL dan nantinya dalam RUKN telah disusun sejalan dengan dokumen induknya? Lebih jauh, perlu untuk ditilik lebih jauh pula apakah rencana proyek pembangkit yang ditetapkan dalam RUPTL telah sejalan dengan komitmen penurunan emisi gas rumah kaca yang tertera dalam NDC Indonesia? 
III. Mengulik RUKN dan RUPTL:

Apakah sejalan dengan dokumen perencanaan induknya?

$\mathrm{Bab}$ ini mencoba menjawab pertanyaan apakah kebijakan perencanaan dalam RUKN dan RUPTL telah disusun dengan mempertimbangkan komitmen perencanaan dokumen induknya maupun potensi yang ada di masingmasing daerah. Untuk itu, ETI tetap digunakan sebagai alat analisis dalam pembahasan ini. Karena tulisan ini lebih terfokus pada bagaimana perencanaan ketenagalistrikan di Indonesia dapat dijadikan alat untuk mengurangi jumlah emisi gas rumah kaca, artikel ini akan lebih fokus pada aspek energy security dan environmental sustainability dalam indeks ETI tersebut.

\section{A. Membedah Aspek Energy \\ Security Dalam RUKN dan RUPTL}

Pada dasarnya, belum ada kesepakatan tunggal terkait dengan definisi Energy Security. Namun Winzer membagi penjelasan terkait energy security ke dalam 3 (tiga) hal, yakni: a) Security of Supply; b) Security of Demand; dan c) Kemampuan untuk menyeimbangkan supply dan demand 312 . Dalam artikel ini, telah dijelaskan sebelumnya bahwa terdapat 2 (dua) hal yang menjadi fokus dalam menilai penerapan aspek energy security dalam RUKN dan RUPTL. Pertama, apakah kapasitas pembangkit yang direncanakan untuk dibangun akan mencapai 115 GW; Kedua, apakah kedua dokumen perencanaan ini benar-benar menggunakan potensi sumber daya setempat sebagai

312 Christian Winzer, "Conceptualizing Energy Security", EPRG Working Paper (University of Cambridge, 2011), 4-5. Bahwa dalam artikel ini dijelaskan lebih lanjut beberapa hal berikut:

a) Menurut Department of Energy and Climate Change (2009), security of supply ini dijelaskan sebagai berikut: "Secure energy means that the risks of interruption to energy supply, are low"

b) Menurut International Energy Agency (2001), security of demand dijelaskan sebagai berikut: "Energy security is defined in terms of the physical availability of supplies to satisfy demand at a given price"

c) Menurut Noel dan Findlater (2010), terkait penyeimbangan antara supply dan demand dapat dijelaskan sebagai berikut: "Security of gas supply refers to the ability of a country's energy supply system to meet final contracted energy demand in the event of a gas supply disruption". 
tumpuan untuk pengembangan pembangkit listrik di daerah tersebut. Adapun untuk memenuhi aspek kedua, hal yang penting untuk dipertimbangkan adalah apakah memang RUPTL telah didesain untuk memaksimalkan penggunaan energi terbarukan serta mengoptimalkan gas bumi sebelum pada akhirnya memilih untuk menggunakan batubara sebagai pasokan energi setempat - seperti yang diamanatkan dalam RUEN.

Untuk melihat penerapan aspek-aspek tersebut dalam RUKN dan RUPTL, berikut adalah tabel perbandingan untuk beberapa provinsi besar:

\begin{tabular}{|c|c|c|c|}
\hline Daerah & $\begin{array}{l}\text { Potensi Sumber } \\
\text { Daya Energi } \\
\text { Setempat } \\
\text { (RUKN) }\end{array}$ & $\begin{array}{l}\text { Potensi Sumber } \\
\text { Daya Energi } \\
\text { Setempat (RUEN) }\end{array}$ & $\begin{array}{c}\text { Perencanaan } \\
\text { Pembangkit (RUPTL) } \\
\text { hingga } 2025\end{array}$ \\
\hline $\begin{array}{l}\text { Aceh } \\
\text { sampai } \\
\text { Lampung }\end{array}$ & $\begin{array}{l}\text { PLT Air/PLT } \\
\text { Minihidro / PLT } \\
\text { Mikrohidro }\end{array}$ & $\begin{array}{l}\text { Paling besar adalah } \\
\text { Surya dan di dalam } \\
\text { RUEN telah } \\
\text { direncanakan } \\
\text { untuk } \\
\text { pembangunan PLT } \\
\text { Surya dengan } \\
\text { kapasitas yang } \\
\text { lebih besar } \\
\text { dibandingkan } \\
\text { pembangkit listrik } \\
\text { berbasis tenaga air } \\
\text { tersebut } 313\end{array}$ & $\begin{array}{l}\text { Adapun di provinsi- } \\
\text { provinsi terkait, berikut } \\
\text { adalah pembangkit listrik } \\
\text { yang menjadi tumpuan di } \\
\text { daerah tersebut hingga } \\
\text { 2025: } \\
\text { 1) Aceh: PLT Air (716 } \\
\text { MW) } \\
\text { 2) Sumatera Utara: PLTU } \\
\text { Batubara (2,100 MW) } \\
\text { 3) Sumatera Barat: PLTU } \\
\text { Batubara 406,5 MW, } \\
\text { namun berdasarkan } \\
\text { pembangkit eksisting. }\end{array}$ \\
\hline
\end{tabular}

313 Lihat, Indonesia (d)., Op.cit., Lampiran I, dari data yang dihimpun dalam lampiran tersebut dapat dilihat bahwa berikut adalah perbandingan potensi PLT Air, PLTM, dan PLT Surya di beberapa provinsi di daerah Aceh hingga Lampung yang dianggap representatif: a) Aceh: PLTS 7,881 MW, PLTM 1,538 MW, PLTA 5,062 PLTA ; b) Sumatera Utara: PLTS 11,821 MW, PLTM 1,024 MW, PLTA 3,808 MW; c) Lampung: PLTS 2,238 MW, PLTM 352 MW; d) Jambi: PLTS 8,847 MW, PLTM 447 MW. Untuk data potensi PLTA di Lampung dan Jambi, data tergabung dalam sistem Sumatera Selatan, Jambi, Bengkulu, dan Lampung, yakni 3,102 MW. 
Untuk pembangkit baru diutamakan PLT Air

4) Riau: Pembangkit Listrik Berbasis Gas (1,223.1 MW), Pembangkit listrik berbasis air tidak direncanakan untuk dibangun, PLTS hanya dalam skala kecil

5) Bangka Belitung: Pembangkit Listrik Berbasis Gas (225 GW), Pembangkit listrik berbasis air tidak direncanakan untuk dibangun, PLTS hanya dalam skala kecil

6) Jambi: PLTU Batubara (1,212 MW)

7) Bengkulu: PLT Panas Bumi (220 MW), rencana pengembangan pembangkit listrik lainnya ditumpukan kepada batubara (200 MW), sementara pembangkit berbasis air hanya untuk kapasitas sangat kecil

8) Lampung: PLTU Batubara (400 MW) 


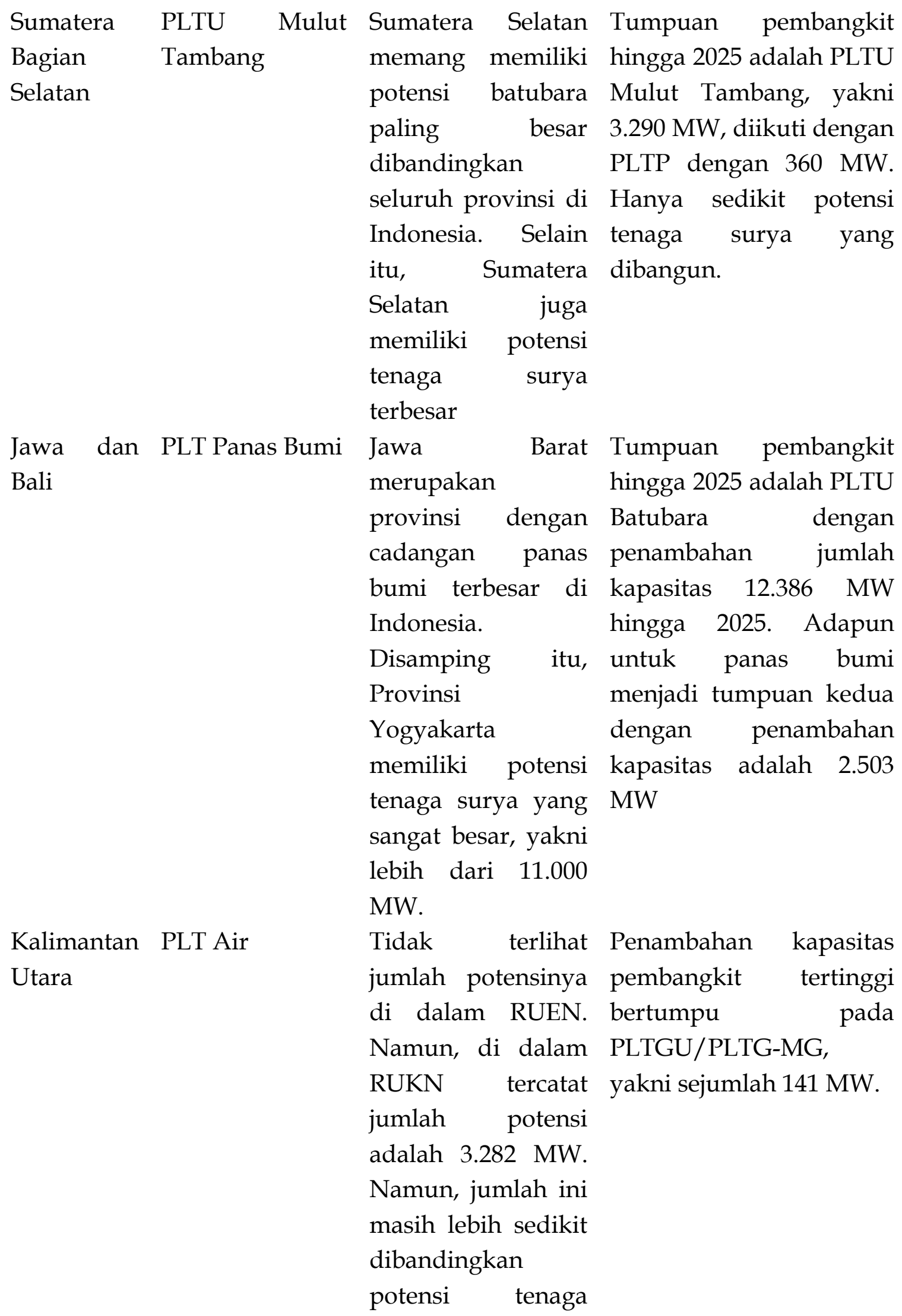




\begin{tabular}{|c|c|c|c|}
\hline & & $\begin{array}{lr}\text { surya } & \text { yang } \\
\text { mencapai } & 4.643 \mathrm{MW}\end{array}$ & \\
\hline $\begin{array}{l}\text { Sulawesi } \\
\text { Utara }\end{array}$ & PLT Panas Bumi & $\begin{array}{l}\text { Tenaga surya dan } \\
\text { tenaga bayu/angin. } \\
\text { Adapun potensi } \\
\text { untuk tenaga surya } \\
\text { adalah mencapai } \\
2.113 \quad \mathrm{MW} \\
\text { Sementara } \\
\text { untuk tenaga bayu } \\
\text { mencapai } \\
\text { MW }\end{array}$ & $\begin{array}{l}\text { Penambahan kapasitas } \\
\text { terbesar bertumpu pada } \\
\text { PLTU Batubara, yakni } 356 \\
\text { MW. Disamping itu juga } \\
\text { PLTGU/PLTG-MG } \\
\text { sebesar } 330 \text { MW. }\end{array}$ \\
\hline $\begin{array}{l}\text { Sulawesi } \\
\text { Tengah } \\
\text { dan Selatan }\end{array}$ & PLT Air & $\begin{array}{l}\text { PLT Air, PLT Surya, } \\
\text { dan PLT Bayu } \\
\text { memiliki potensi } \\
\text { yang sangat besar. }\end{array}$ & $\begin{array}{l}\text { Penambahan PLT Air } \\
\text { menjadi tumpuan } \\
\text { kapasitas pembangkit } \\
\text { terbesar dengan rencana } \\
\text { penambahan pembangkit } \\
960 \mathrm{MW} \text { di Sulawesi } \\
\text { Selatan dan } 320 \mathrm{MW} \mathrm{di} \\
\text { Sulawesi Tengah }\end{array}$ \\
\hline $\begin{array}{l}\text { Maluku } \\
\text { dan } \\
\text { Maluku } \\
\text { Utara }\end{array}$ & $\begin{array}{l}\text { PLTG/PLT-MG, } \\
\text { namun untuk } \\
\text { Ambon dan } \\
\text { Halmahera } \\
\text { dapat } \\
\text { diprioritaskan } \\
\text { PLT Panas Bumi }\end{array}$ & $\begin{array}{l}\text { PLTG/PLT-MG. } \\
\text { Disamping itu, } \\
\text { potensi PLT Bayu } \\
\text { juga tergolong } \\
\text { besar, yakni } 3.188 \\
\text { MW. }\end{array}$ & $\begin{array}{l}\text { PLTG/PLT-MG menjadi } \\
\text { tumpuan pembangkit, } \\
\text { yaitu dengan } \\
\text { penambahan pembangkit } \\
\text { sebanyak } 575 \mathrm{MW} \text {. }\end{array}$ \\
\hline
\end{tabular}

Tabel 2. Perbandingan Potensi dan Perencanaan Pembangkit

Dari data tersebut dapat dilihat bahwa tidak semua penetapan dalam RUKN terkait potensi sumber daya energi setempat yang harus dikembangkan sesuai dengan potensi sumber daya terbesar yang terdata dalam RUEN. Terlebih ketika rencana ini diterjemahkan ke dalam RUPTL. Dari beberapa provinsi besar yang dipilih untuk dijadikan analisis, terlihat bahwa RUPTL belum didesain untuk 
menggunakan potensi energi setempat sebagai tumpuan pembangkit listrik di daerah tersebut. Justru, di beberapa provinsi, PLTU Batubara tetap digunakan sebagai pembangkit andalan di provinsi setempat, sekalipun RUEN telah menyatakan bahwa seharusnya batubara digunakan sebagai pilihan terakhir dalam penyediaan energi di suatu daerah.

Sulawesi Utara adalah contoh tidak digunakannya potensi sumber daya setempat. Ketika tenaga surya dan tenaga angina diidentifikasi sebagai potensi terbesar dari daerah terkait, namun di sisi lain RUPTL menetapkan bahwa penambahan kapasitas terbesar bertumpu pada PLTU Batubara. Pun ketika menelisik ke pengembangan di Jawa dan Bali, baik Jawa Barat maupun Banten misalnya, masing-masing memiliki potensi energi surya dan energi angin yang sangat besar sebagai potensi setempat ${ }^{314}$. Namun justru dalam pengembangan pembangkit listrik, PLTU Batubara-lah yang menjadi pilihan, sementara itu pengembangan untuk PLTS dan PLTB sangat minim dan tidak sebanding 315 . Karenanya, perlu untuk dikaji kembali lebih lanjut bagaimana proses pengambilan keputusan oleh PT. PLN (Persero) untuk pada akhirnya menetapkan suatu potensi sumber daya alam menjadi sumber energi tumpuan daerah tersebut.

Selain perlu mengkritisi proses pengambilan kebijakan di PT. PLN (Persero) sendiri, perlu juga melihat bagaimana rencana target penambahan kapasitas untuk mencapai 115 GW pada tahun 2025. Pada kenyataannya, RUPTL juga belum didesain untuk memenuhi target total kapasitas

314 Lihat, Indonesia (d)., Ibid. Dalam lampiran Peraturan tersebut terlihat bahwa potensi energi surya untuk Jawa Tengah adalah 8,753 MW dan Banten adalah 2,461 MW. Selain itu untuk potensi energi bayu untuk Jawa Tengah adalah7,036 MW dan 1753 untuk Banten.

315 Menteri Energi dan Sumber Daya Mineral, Keputusan Menteri Energi dan Sumber Daya Mineral tentang Pengesahan Rencana Usaha Penyediaan Tenaga Listrik PT. Perusahaan Listrik Negara (Persero) Tahun 2018 s.d 2027, Kepmen No. 1567 K/21/MEM/2918. Tercatat dalam RUPTL adalah bahwa rencana pembangkit untuk PLTU-B untuk Banten adalah 4,637 MW untuk Banten dan 4,845 MW untuk Jawa Tengah hingga 2025. Jumlah ini sangat berbanding terbalik dengan pengembangan PLTS dan PLTB; dimana untuk di Jawa Tengah hanya dialokasikan 100 MW untuk PLTS dan PLTB, serta di Banten hanya 300 MW untuk PLTS dan PLTB. 
tersebut. Hingga saat ini, baru sekitar $53 \mathrm{GW}^{316}$ kapasitas terpasang. Selain itu, apabila keseluruhan jumlah rencana pembangkit dalam RUPTL dijumlahkan dengan kapasitas yang telah terpasang, baru sekitar 104 GW $^{317}$ yang akan terpasang pada tahun 2025. Hal ini tentu tidak sesuai dengan perencanaan untuk pemenuhan kapasitas pembangkit pada tahun 2025. Oleh karena itu, dari aspek pemenuhan kapasitas pembangkit dapat dikatakan bahwa RUPTL-pun belum didesain untuk pemenuhan energy security di Indonesia.

\section{B. Pemenuhan Environmental}

\section{Sustainability}

Untuk menilai pemenuhan aspek environmental sustainability, Penulis mencoba mengkaji apakah RUPTL telah didesain untuk memenuhi rencana pengembangan pembangkit dari energi baru dan terbarukan sebanyak 23\% atau sekitar 26 GW. Sekalipun dari aspek perencanaan dalam RUEN, target pengembangan EBT adalah 33\%, namun terlihat bahwa $10 \%$-nya adalah potential projects dan bukan committed projects. Mengingat belum jelasnya definisi dari potential projects dan committed projects, artikel ini menggunakan committed projects sebagai landasan analisis. Berikut adalah perbandingan tabel perencanaan pembangkit listrik berbasis energi baru terbarukan antara RUEN dan RUPTL hingga tahun 2025: pembangunan

\begin{tabular}{lcc}
\multicolumn{1}{c}{ Jenis Pembangkit } & $\begin{array}{c}\text { Rencana } \\
\text { pembangunan } \\
\text { dalam RUEN }\end{array}$ & $\begin{array}{c}\text { Rencana } \\
\text { pembangunan } \\
\text { dalam RUPTL }\end{array}$ \\
Panas Bumi & $7.241,5 \mathrm{MW}$ & $6.184,7 \mathrm{MW}$ \\
Air & $13.986,7 \mathrm{MW}$ & $10.847,9 \mathrm{MW}$ \\
Minihidro dan Mikrohidro & $1.572,1 \mathrm{MW}$ & $986,5 \mathrm{MW}$ \\
& \\
Data diolah oleh Penulis dengan menghimpun seluruh jumlah kapasitas pembangkit terpasang \\
Data diolah oleh Penulis dengan menghimpun jumlah seluruh rencana kapasitas pembangkit \\
Dinsi dan per jenis pembangkit yang terdapat dalam lampiran RUPTL 2018-2027.
\end{tabular} per provinsi yang terdapat dalam lampiran RUPTL 2018-2027. \\ ${ }^{317}$ Data diolah oleh Penulis dengan menghimpun jumlah seluruh rencana kapasitas pembangkit per provinsi dan per jenis pembangkit yang terdapat dalam lampiran RUPTL 2018-2027.}




\begin{tabular}{|c|c|c|}
\hline Bioenergi & 2.006 MW & 187,5 MW \\
\hline Surya & 540,5 MW & $149,81 \mathrm{MW}$ \\
\hline Angin & 913,9 MW & 1.030,75 MW \\
\hline EBT lainnya & $372 \mathrm{MW}$ & $320,5 \mathrm{MW}$ \\
\hline Total & 26.632,7 MW & $19.697,66 \mathrm{MW}$ \\
\hline
\end{tabular}

Berdasarkan data yang dihimpun tersebut, tergambar Selain itu, perlu juga informasi bahwa pada dasarnya mengkritisi komitmen dari Pemerintah untuk memenuhi perencanaan dalam RUPTL memang belum di desain untuk mencapai target $23 \%$ bauran energi baru dan terbarukan tersebut. Apabila seluruh kapasitas pembangkit yang sudah ada per provinsi ditambahkan dengan rencana pembangunan pembangkit listrik hingga 2025, maka terlihat bahwa kapasitas maksimum dari pengembangan pembangkit listrik berbasis energi baru terbarukan hanya sekitar maksimum $17 \%$. Angka ini adalah jumlah dengan catatan bahwa seluruh proyek akan berjalan lancar. target pembangunan pembangkit berbasis Energi Baru Terbarukan (EBT) ini. Berdasarkan data yang diperoleh dari RUPTL 2018-2027, pada awal tahun 2018 hingga 2024, pengembangan pembangkit listrik berbasis EBT masih belum terlihat secara masif. Namun, pada tahun 2025 terjadi penambahan angka pembangkit listrik berbasis EBT yang sangat drastis. Berikut adalah tabel perkembangan pembangkit listrik berbasis EBT (khususnya PLTA, PLTS, dan PLTP) per tahun hingga 2025: 


\begin{tabular}{lllllllll} 
Pembangkit & \multicolumn{8}{c}{ Rencana Kapasitas Pembangkit (dalam MW) } \\
& $\mathbf{2 0 1 8}$ & $\mathbf{2 0 1 9}$ & $\mathbf{2 0 2 0}$ & $\mathbf{2 0 2 1}$ & $\mathbf{2 0 2 2}$ & $\mathbf{2 0 2 3}$ & $\mathbf{2 0 2 4}$ & $\mathbf{2 0 2 5}$ \\
PLTA & 66 & 287 & 193 & 755 & 315 & 196 & 115 & 2.041 \\
PLTP & 210 & 150 & 221 & 235 & 405 & 445 & 355 & 2.537 \\
PLTS & - & - & - & - & - & - & 520 & 2.420
\end{tabular}

Tabel 4. Perkembangan Penambahan Kapasitas per Tahun untuk PLTA, PLTP, dan PLTS $^{318}$

Dari data tersebut, perlu dikaji lebih lanjut bagaimana perencanaan pengembangan kapasitas pembangkit berbasis energi baru terbarukan. Mengapa pada akhirnya pengembangan kapasitas pembangkit listrik tersebut menjadi bertambah 4 (empat) kali lipat mendekati tahun 2025? Pola pengembangan kapasitas pembangkit seperti ini tentu terlihat tidak realistis dan perlu untuk dipertanyakan lebih lanjut. Tidak hanya itu, perlu juga mempertanyakan terkait rencana pengembangan kapasitas pembangkit untuk PLTS maupun PLTB (Pembangkit Listrik Tenaga Bayu/Angin).

Berdasarkan data yang
dihimpun dari $\quad$ RUEN,
keseluruhan potensi energi untuk
surya dan angin pada dasarnya
sangat besar. Apabila potensi
energi seluruh Indonesia
dijumlahkan, PLTS dapat
mencapai 207 GW dan PLTB
mencapai 61 GW319. Namun,
dalam penetapan rencana
pembangkit di RUPTL, untuk
PLTS ditetapkan hanya 172,58
MW dan PLTB hanya sekitar 1
GW. Hal ini jauh dibawah rencana
penambahan pembangkit PLTU
Batubara yang mencapai 25 GW
dari 2018-2027.
Mahwa kedua energi ini termasuk

318 Menteri Energi dan Sumber Daya Mineral., Op.cit., V-35

319 Indonesia (d)., Ibid. 
dalam energi yang bersifat intermittent (bersifat sewaktuwaktu), sehingga pengembangannya cukup sulit dan memiliki tantangan dalam pengembangan sistem transmisinya ${ }^{320}$. Namun, Penulis berpendapat seharusnya Pemerintah dapat lebih mendorong pengembangan infrastruktur untuk menyokong integrasi grid (jaringan) untuk pembangkit yang bersifat intermittent tersebut daripada terus mendorong pembangunan PLTU Batubara atas alasan lebih ekonomis dan untuk memenuhi energy security. Untuk itu, Penulis berargumen bahwa perencanaan ketenagalistrikan di Indonesia, khususnya RUPT belum didesain pula untuk memenuhi aspek environmental sustainability.

\section{Penutup}

Berdasarkan pemaparan pada bab sebelumnya, maka terdapat dua hal yang menjadi kesimpulan dalam penulisan artikel ini, yakni:

(1) Bahwa

berdasarkan penelusuran konsistensi arah kebijakan ketenagalistrikan di dalam empat dokumen perencanaan ketenagalistrikan, terlihat bahwa perencanaan kebijakan ketenagalistrikan di Indonesia belum sejalan satu sama lain. Ketidakkonsistenan yang paling jelas terlihat dalam komitmen untuk menggunakan batubara sebagai pilihan terakhir dalam pemenuhan energi di masing-masing daerah. Selain itu, hal yang juga perlu diperhatikan adalah terkait dengan target-target perencanaan antara satu dokumen dengan dokumen

320 J.O. Petinrin dan M. Shaaban, "Overcoming Challenges of Renewable Energy on Future Smart Grid", Telkomnika 10 (Jakarta 2012), hlm. 230. Bahwa dalam artikel tersebut dijelaskan dalam pengembangan grid yang konvensional sangat bergantung pada konsistensi aliran listrik yang dapat masuk ke dalam grid tersebut. Hal ini menjadi tantangan tersendiri bagi pengembangan pembangkit listrik berbasis energi terbarukan, mengingat dengan sifatnya yang intermittent, konsistensi aliran listrik-pun menjadi tidak stabil dan fluktuatif. 
lainnya. Bahwa terdapat

ketidakkonsistenan dalam

dokumen-dokukem

perencanaan tersebut antara target jumlah pemenuhan kapasitas pembangkit secara keseluruhan serta target pembangkit listrik berbasis EBT pada tahun 2025.

(2) Berkaitan dengan target untuk pengurangan emisi gas rumah kaca dari sektor energi dalam NDC, artikel ini melihat bahwa RUPTL belum disusun untuk mendukung komitmen tersebut. Bahwa proyek-proyek pembangkit tenaga listrik yang ditetapkan dalam RUPTL belum dirancang untuk memenuhi target $23 \%$ pengembangan energi terbarukan. Sebaliknya, penambahan kapasitas pembangkit yang bertumpu pada batubara tetap menjadi tumpuan. Selain itu, hal yang perlu juga diperhatikan adalah adanya pola pengembangan pembangkit listrik berbasis EBT yang tidak realistis. Adapun dari temuan dalam RUPTL, rencana pembangunan pembangkit listrik berbasis EBT pada tahun 2018-2024 masih dalam angka yang sangat minim, kemudian pada tahun 2025 meningkat drastis hingga empat kali lipat. Hal ini tentu menimbulkan keraguan terkait bagaimana strategi yang dilakukan untuk pemenuhan kapasitas tersebut. Lebih jauh, artikel ini melihat bahwa pemenuhan target pengurangan emisi gas rumah kaca di Indonesia sebagaimana tercantum dalam Nationally Determined Contribution (2017) akan semakin sulit apabila tidak diterjemahkan secara baik dalam kebijakan-kebijakan perencanaan ketenagalistrikan tersebut. 


\section{DAFTAR PUSTAKA}

\section{Peraturan Perundang-Undangan}

Indonesia. Peraturan Pemerintah tentang Kegiatan Usaha Penyediaan Tenaga Listrik, Peraturan Pemerintah No. 14 tahun 2012, LN No. 28 tahun 2012, TLN No. 5281

. Peraturan Pemerintah tentang Perubahan Atas Peraturan

Pemerintah Nomor 14 Tahun 2012 tentang Kegiatan Usaha Penyediaan Tenaga Listrik, PP No. 23 Tahun 2014, LN No. 75 Tahun 2014, TLN No. 5530.

- Menteri Energi dan Sumber Daya Mineral, Keputusan Menteri Energi dan Sumber Daya Mineral tentang Pengesahan Rencana Usaha Penyediaan Tenaga Listrik PT. Perusahaan Listrik Negara (Persero) Tahun 2018 s.d 2027, Kepmen No. 1567 K/21/MEM/ 2918.

\section{Buku}

Masripatin, Nur, et.al. Strategi Implementasi NDC (Nationally Determined Contribution). Jakarta: Dirjen Pengendalian
Perubahan Iklim, KLHK RI. 2017.

\section{Lain-lain}

Petinrin, O. dan M. Shaaban, "Overcoming Challenges of Renewable Energy on Future Smart Grid", Telkomnika 10. Jakarta. 2012.

Song, Lianlian, et.al., "Measuring National Energy Performance via Energy Trilemma Index: A Stochastic Multicriteria Acceptability Analysis". Energy Economics. 2017.

Winzer, Christian "Conceptualizing Energy Security", EPRG Working Paper University of Cambridge. 2011.

World Energy Council, Membedah Perencanaan Ketenagalistrikan, http://www.djk.esdm.go.id/pd f/Coffee\%20Morning/Juli\%202 016/Membedah\%20Perencanaa n\%20Ketenagalistrikan\%20Nasi onal\%20-\%20Dr.\%20Hardiv\%20HS.pdf, diakses pada 18 Oktober 2018. 